\title{
APPLYING THE THEORY OF CONSTRAINTS TO INCREASE ECONOMIC VALUE ADDED: PART 1-THEORY
}

\author{
Malan Smith ${ }^{1}$ \\ Siemens Telecommunications (Pty) Ltd \\ P.O. Box 912469 \\ Silverton 0127, South Africa \\ malans@siemens.co.za \\ Pieter Pretorius \\ Department of Engineering and Technology Management \\ Faculty of Engineering, the Built Environment and Information Technology \\ University of Pretoria \\ Pretoria 0002, South Africa \\ pieter.pretorius@eng.up.ac.za
}

\begin{abstract}
This article, presented in two parts, explains how to apply the Theory of Constraints (TOC) in a business to increase Economic Value Added (EVA). The first part deals with the theory, while the second part deals with the implementation. The goal of a business, the measurements of the goal and the priority of the measurements are discussed. The future reality of a company which implements TOC principles is shown through cause and effect to lead to an increase in EVA. The increase in EVA is caused by an increase in return on investment and a reduction in the cost of capital. The actions the company must take to increase EVA is presented.
\end{abstract}

\section{OPSOMMING}

Hierdie artikel, aangebied in twee dele, verduidelik hoe om die Teorie van Beperkinge (TVB) in a besigheid toe te pas om Ekonomiese Toegevoegde Waarde (ETW) te vermeerder. Die eerste gedeelte verduidelik die teorie, terwyl die tweede gedeelte die toepassing hanteer. Die doel van 'n besigheid, die maatstawwe van die doel en die prioriteit van die maatstawwe word bespreek. Deur middel van oorsaak en effek word gewys dat die toekomstige werklikheid van 'n besigheid wat TVB beginsels toepas lei tot 'n toename in ETW. Die toename in ETW word veroorsaak deur 'n toename in opbrengs op belegging en 'n afname in die koste van kapitaal. Die aksies wat 'n besigheid moet neem om ETW te vermeerder, word genoem.

\footnotetext{
${ }^{1}$ This author was at the time of writing the article enrolled for an M.Sc (Engineering Management) in the Department of Engineering and Technology Management, University of Pretoria.
} 


\section{Introduction}

Goldratt's Theory of Constraints (TOC) is a systems approach to describing and solving problems. TOC is based on the observation that every company must have a constraint, otherwise it would be producing an infinite stream of profits. Although originally seen as a theory of production, as described in the book "The Goal" [1], it is now recognised that the thinking processes that underpin the TOC have application to other business systems. The method has been successfully applied to a wide range of problems in such diverse fields as marketing, project management, strategy, human resource management etc. Due to the systems approach underpinning TOC, the aim is always to achieve a global optimum.

Economic Value Added (EVA), promoted by the consulting firm Stern, Stewart \& Co, is a measure of the financial success of a business [2]. This financial success is measured in terms of the excess return above a certain expected return. The expected return is determined by the shareholders of the company, or through the valuation of the company on the stock market. The aim is to tie management incentives to the EVA achieved, thus aligning management compensation with the shareholders expectations. Due to the strong shareholder orientation of the system, many companies are introducing EVA. Since EVA measures excess return on investment, when the company increases EVA it moves towards the goal of maximising return on investment.

In order to measure how well management has met their commitment to shareholders, various measurement systems have been designed. Stewart [2] claims that EVA is the most effective measure to ensure this. In financial publications, (e.g. Financial Mail [3] and [4], and Fortune [5] and [6]), anecdotal evidence for the success of EVA is presented. However, most of the strategies presented by Stewart refers to financial planning and financial engineering. This is a good strategy for the financial director to increase EVA. However, since the company is a system, local improvements in one area could have adverse effects in others. It has been demonstrated how the application of EVA can actually lead to local optima instead of global optima [16]. Therefore, holistic strategies to increase EVA (without adverse side-effects), must be found. Currently TOC is gaining acceptance outside production and operations, and could prove to hold some of the key answers to ensure that all divisions of the company contribute to shareholder value.

\section{The goal of a business}

Ackoff [7] refers to a purposeful system as a system which can change its goals under constant conditions, i.e. it displays free will. The goal of a purposeful system is defined as " $a$ preferred outcome that can be obtained within a specified time period," the objective is defined as "a preferred outcome that cannot be obtained within a specified period but which can be obtained over a longer time period," and an ideal is defined as "an objective which cannot be obtained in any time period but which can be approached without limit" [7]. Since the organisation is a purposeful system (see [8]), it implies that goals, objectives and ideals exist within the organisation. Even if these goals, objectives and ideals are not explicitly set, they are implicitly communicated through for example budgets, value statements, etc.

If the ends (goals, objectives and ideals) of the organisation are not explicitly communicated, then there is no measure of success or failure in an organisation. Since most organisations 
have a clear sense of what success or failure is, it means that the ends are at least implicitly communicated.

The Theory of Constraints, as a systems theory, places a strong emphasis on the measurement of the system. As Eli Goldratt explains: "TELL ME HOW YOU MEASURE ME, AND I WILL TELL YOU HOW I WILL BEHAVE. IF YOU MEASURE ME IN AN ILLOGICAL WAY. . DO NOT COMPLAIN ABOUT ILLOGICAL BEHAVIOUR” [9]. To ensure logical behaviour, TOC strives for a logical measurement system that causes behaviour that enables decisions which will create global optima.

To measure, the ends of the system must therefore be defined. In TOC, the system is measured against a goal (which is a combination of goal, objective and ideal according to Ackoff's definition). The goal of a business (i.e. a for-profit organisation) is defined as "make money now as well as in the future" [10]. The goal is supported by necessary conditions: if a necessary condition is violated, the goal cannot be reached [10]. The necessary conditions that are needed to ensure the fulfilment of the goal, are to "provide a secure and satisfying environment for employees now as well as in the future," and to "provide satisfaction to the market now as well as in the future" [10]. To reach the goal, the necessary conditions apply: if a company does not have employees that feel secure in their jobs, then in the long run employees become demotivated and the results of the company are suboptimal. Also, if a company's products or services do not deliver value to the customer, the company cannot provide satisfaction to the market and the company cannot prosper in the long run.

Productivity is defined in terms of the goal: "every action that brings a company closer to its goal is productive. Every action that does not bring a company closer to its goal is not productive” [1].

Proper measurement of the goal. If the goal is to make money now as well as in the future, then the measurement of a for-profit company should be in terms of money generated. The question that arises is how the measurement should take place? Should the money generated be measured in terms of the financial statements of the company? It can be shown that financial statements can distort reality (see [11]), and that to calculate EVA, numerous adjustments need to be made in order to gain insight into the true economic value generated by the company [2]. Therefore measurements based on financial statements drawn up according to generally accepted accounting principles might not always reflect the true status of the business.

The measurements of TOC can be defined by considering the specifications of a moneymaking machine, which is an analogy for a for-profit organisation. The first specification of such a machine would be the rate at which it generates money: a machine that generates money faster would be superior to one that generates money at a slower rate. Another specification of a money-making machine would be the money captured in the machine (money needed within the machine that cannot be removed - it is necessary for the machine's operation - and includes the purchase price of the machine), and also the money needed to operate and maintain the machine. Knowing these specifications of the machine, enables one to make a full evaluation of the amount of money that the machine can generate, and whether this is economically feasible in terms of investment and expenditure [12]. 
In order to judge the economic feasibility, it is therefore necessary to know the return on investment generated by the machine, the investments necessary to obtain the machine and generate money from the machine, and the operating expenses necessary to operate, maintain and depreciate the machine. To be able to calculate return on investment, it is necessary to know the net profit (NP) obtained from the machine over a specific time period, and investment (I) that was made to obtain the machine and generate the net profit. If these quantities are known, return on investment (ROI) can be calculated as follows:

$$
\mathrm{ROI}=\frac{\mathrm{NP}}{\mathrm{I}}
$$

The net profit (NP) can be calculated from the difference between all the money generated, called per definition the throughput $(\mathrm{T})$ of the machine, and the operating expenses $(\mathrm{OE})$ of the machine:

Therefore:

$$
\mathrm{NP}=\mathrm{T}-\mathrm{OE}
$$

$$
\mathrm{ROI}=\frac{\mathrm{T}-\mathrm{OE}}{\mathrm{I}}
$$

The definitions of the TOC measurement parameters are as follows [13]:

- "Throughput: The rate at which the organisation generates 'goal units';

- Operating Expense: All the money the organisation spends in generating 'goal units';

- Investment: The money tied up in the organisation".

The origins of the TOC measurements were in operations. The major proportion of investment in operations was in inventories at the time, and therefore "inventory" was the appropriate term to use for investment. In more recent TOC literature, the more general word "investment" is used, although the definition is the same. The definition of throughput is in terms of "goal units" to show that the TOC is also applicable to non-profit organisations, if the appropriate goal units are chosen. For a profit-oriented organisation, the goal is to make money now as well as in the future, therefore the goal units are a monetary measurement. Net profit and return on investment can be measured only in a for-profit organisation.

Throughput is further defined as "sales minus truly variable costs" [14]. Truly variable means costs that can be measured and avoided by not creating and selling the specific product that generates the sales. This means that most labour is a fixed cost and part of operating expense, not of variable costs. A good test for variable cost is to ask: if this product is not manufactured, which material does not need to be bought any more, which people can be fired, which machines can the company sell etc. If the above type of question cannot be answered positively (or is answered as "two hours of this machine is free," or "one hour of that person's time is saved"), then the costs are fixed (therefore operating expense), and not variable. An example of the wrong application of variable costs (due to inertia and the wrong paradigm) is acknowledged in some sources (e.g. [15]). In this specific source material and labour are classified as variable costs, then concludes "in practice, while direct materials are almost always fully variable, direct labour is more than likely to be largely fixed" [15]. Despite this correct notion, the authors, then anyway makes the calculation as though labour is a variable cost! Also, throughput is a cash measure, therefore sales on credit (or debtors on 
book) are a part of investment. Throughput is only recognised once cash has been received for the sale, which is different from when revenue is recognised in normal accounting practices.

The final measurement of corporate performance is cash flow. Cash flow (CF) is the amount of money of net profit left after changes in investment have been accounted for:

$$
\mathrm{CF}=\mathrm{T}-\mathrm{OE}-? \mathrm{I}
$$

Negative investment, or a decrease in inventories/investment, therefore increases the cash flow of the business.

Priority of the measurements. When the formula for net profit (equation 2) is analysed, it seems that both throughput and operating expense have the same priority. To increase net profit by one unit, it is possible in two ways: increase throughput by one unit, or decrease operating expense by one unit. Over which measurement does the manager in his local area have control? Operating expense is within each manager's control (see [16]). Therefore, in most organisations, operating expense is the highest priority measurement, since throughput is seen as outside most parts of the organisation's control. Most efforts are therefore directed at decreasing operating expense. If operating expense is the most important measurement, which of throughput and investment is the next most important? Investment only occurs in the return on investment formula (equation 1), and throughput affects both net profit and ROI, therefore throughput is seen as more important than investment. This priority of measurements - decrease $\mathrm{OE}$, increase $\mathrm{T}$, decrease $\mathrm{F}$ is part of the paradigm called the "cost world" in TOC terminology [17].

If the focus of the company is a process of ongoing improvement, which measurement should be the most important? If the objective of the company is to increase profitability, should it focus on reducing cost, reducing investment or increasing throughput? What is the limit on improvement in investment and operating expense? Zero. What is the limit on improvement in throughput? Infinite! What is the goal of the company? To make money, now as well as in the future. Can the company make money with zero investment and operating expense? No, it will have to close down. Therefore, throughput should be the focus of improvement, since this can increase without limit, and therefore be continuously improved-the business was created to make money, not to save costs. It is important to note that TOC does not claim reducing operating expenses is not important: it merely states that it should not be the primary focus of improvement activities. At best operating expense reductions are limited by zero and could easily damage the capability of the company to generate throughput, since the local impact of an operating expense reduction has no relation to the global impact of that reduction (see [18]). Which of the measures investment and operating expense should have the second priority? In the western world, it is acknowledged that investment has a cost associated with it. In many organisations, inventories form a major portion of the total investment of the company. In addition, work-in-progress inventories have a major impact on the ability of an operation to generate throughput, since work-in-progress inventories have a direct impact on the flexibility, lead-time and quality of an operation (see [1] and [24]). Therefore the reduction of work-in-progress should be the next priority since it has a major impact on throughput. This set of priorities-increase $\mathrm{T}$, decrease $\mathrm{I}$, decrease $\mathrm{OE}$ - is part of the paradigm called the "throughput world" [17]. The priorities of TOC are compared with other management approaches in Table 1. 


$\begin{array}{lll}\text { Traditional } & \text { Japanese } & \text { TOC } \\ \text { 1. Decrease OE } & \text { 1. Decrease I } & \text { 1. Increase T } \\ \text { 2. Increase T } & \text { 2. Increase T } & \text { 2. Decrease I } \\ \text { 3. Decrease I } & \text { 3. Decrease OE } & \text { 3. Decrease OE }\end{array}$

Table 1. Management priorities [19]

The calculation of Economic Value Added. In order to be able to calculate the EVA of a business, the rate of return on capital and the cost of the capital employed to generate that return must be calculated. The rate of return $r$ on the capital of the business is calculated as follows from the net operating profit after tax (NOPAT) [2]:

$$
\mathrm{r}=\frac{\text { NOPAT }}{\text { capital }}
$$

The cost of capital, c, is the weighted average cost of debt, owners' equity and preferential shares. The calculation of EVA is then done as follows [2]:

$$
\begin{aligned}
\text { EVA } & =(\text { rate of return }- \text { cost of capital }) \times \text { capital } \\
& =(\mathrm{r}-\mathrm{c}) \times \text { capital } \\
& =\mathrm{r} \times \text { capital }-\mathrm{c} \times \text { capital } \\
& =\text { NOPAT }-\mathrm{c} \times \text { capital } \\
& =\text { operating profits }- \text { a capital charge }
\end{aligned}
$$

Therefore, the EVA of a business is the operating profits generated minus a charge for the use of capital. This is exactly the same as the definition of the residual income method, therefore EVA is a variant of the capital budgeting method [11].

The EVA of the business can be increased in three ways [16]:

- $\quad$ increase the net profit margin;

- $\quad$ increase the total asset turnover;

- decrease the cost of capital.

\section{Hypothesis and future reality tree of the organisation}

The challenge is to apply the knowledge about EVA and TOC, and to determine whether the use of a TOC based management approach in an organisation, may lead to the desired effect of an increase in EVA. Thus, the hypothesis is that the application of TOC will lead to an increase in EVA. The TOC method to represent the results of a planned course of action, is the future reality tree. The future reality tree "is a sufficiency-based logic structure designed to reveal how changes to the status quo would effect reality-specifically to produce desired effects" [20]. The future reality tree of an organisation that implements management according to TOC principles is depicted in Figures 1 and 2.

Reading a logic tree. A logic tree can be read by understanding how the cause and effect logic is represented (refer to Figure 1). In this case, the tree is a future reality tree, which contains square boxes, round boxes, arrows, ovals and circles. The numbers in the boxes are 
for reference to a particular element of the tree, and have no significance on its own. A square box in the future reality tree is called an "injection." An injection is "a condition, circumstance or action that doesn't exist now" [19]. A round box is an effect or an existing condition of reality. The logical connections are indicated by the arrows. The box on which the arrow originates, is preceded by the word "if," and the box where the arrow ends, is preceded by the word "then." For example, the logical connection between entity 90 and 95 is read as follows: "if the company decides to manage according to TOC principles and implements the decision (90), then the company continuously improves the measurements $\mathrm{T}$, I and OE (95)." Entity 95 is an effect of 90, and 90 is a precondition for the existence of 95 . The oval is read as "and." For example, the connections of entities 100, 110 and 130 are read as follows: "if the measurements $\mathrm{T}, \mathrm{I}$ and $\mathrm{OE}$ are used at all levels of the decision making group (100), and all decisions are made in terms of their effect on T, I and OE, and in priority of T highest and OE lowest (110), then many suboptimal decisions are eliminated (130)." The circles refer to entities that are on other diagrams, in this case Figure 2. The desired effects in the tree are shown in bold type.

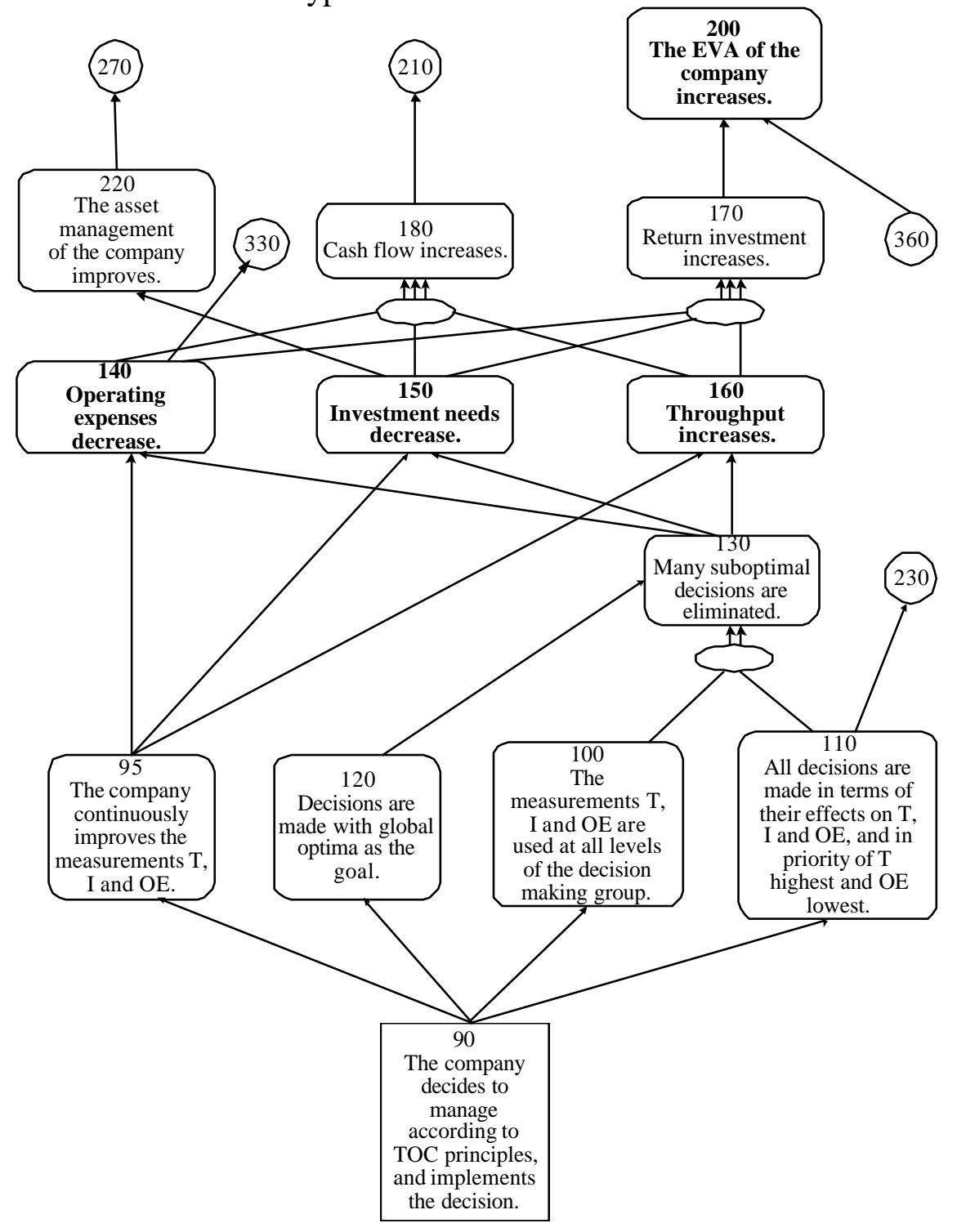

Figure 1. Applying TOC measurements future reality tree 
Future reality tree of implementing TOC in the organisation. The starting point is to introduce TOC as the underlying principle of management in the company. This approach strives for optimal system solutions rather than local optima by focussing on the system's constraint. The detail of this management philosophy is discussed in a number of publications (e.g. [1], [9], [10], [12], [13], [14], [17], [19] , [20] [21] and [24]). Implementation of a TOC based management approach will be discussed in part two of this article [23]. When the company decides to man-age according to TOC principles and implements the decision (90), then the company continuously improves the measurements T, I and OE (95). Also, decisions are made with global optima as the goal (120), the measurements T, I and OE are used at all levels of the decision making group, and all decisions are made in terms of their effects on $\mathrm{T}$, I and OE, and in priority of T highest and OE lowest (110). The effects 95, 120, 100 and 110 are all directly caused by the introduction of management according to TOC principles.

If the measurements T, I and OE are used at all levels of the decision making group (100), and all decisions are made in terms of their effects on T, I and OE, and in priority of T highest and OE lowest (110), then many suboptimal decisions are eliminated (130). The usual suboptimal effect of local decision making can therefore be eliminated if every one involved in decision making are using the TOC performance measurements, and can correctly judge the effect of decisions in terms of the TOC performance measurements. Also, if decisions are made with global optima as the goal (120), then many suboptimal decisions are eliminated (130). Following the five focusing steps of TOC ensure that decision making is focused on the constraints of the organisation [1]. Improvement at the constraint has an immediate bottom line impact on the results of the organisation.

If the company continuously improves the measurements T, I and OE (95), then operating expenses decrease (140), investment needs decrease (150) and throughput increases (160). Also, if many suboptimal decisions are eliminated (130), then operating expenses decrease (140), investment needs decrease (150) and throughput increases (160). If operating expenses decrease (140) and investment needs decrease (150) and throughput increases (160), then return on investment increases (170) (see equation (1)). But return on investment is part of the calculation of EVA (see equations (5) and (6)), therefore if return on investment increases (170), then the EVA of the company increases (200).

Also, by equation (4), if operating expenses decrease (140) and investment needs decrease (150) and throughput increases (160), then cash flow increases (180). The company has two main categories of assets: fixed and current. A major portion of the assets of the company can be tied up in working capital. If the working capital cycle of the company is improved through less inventories, it is possible to focus better on the assets available. Therefore the amount of obsolescence, bad debtors, etc. should decrease. Also, if the focus is on utilising the fixed assets effectively, then the fixed asset base of the company does not need to increase yearly. (Note that fixed investment should only be committed if a lack of fixed investment constrains the throughput of the company.) Therefore, if investment needs decrease (150) then the asset management of the company improves (220).

In Figure 2 the second part of the future reality tree of the company is explained. If cash flow increases (180) then the company has cash to fund new investment internally (210). If all decisions are made in terms of their effect on $\mathrm{T}, \mathrm{I}$ and $\mathrm{OE}$, and priority of $\mathrm{T}$ highest and $\mathrm{OE}$ the lowest (110), then there is a strong focus on increasing throughput (230). There are two 
ways to increase throughput once the market becomes a constraint: market the same offerings in different market segments, or expand the company's offerings [22]. If there is a strong focus on increasing throughput (230) and the company finds new ways to market its current offerings (240), then throughput increases (160). If there is a strong focus to increase

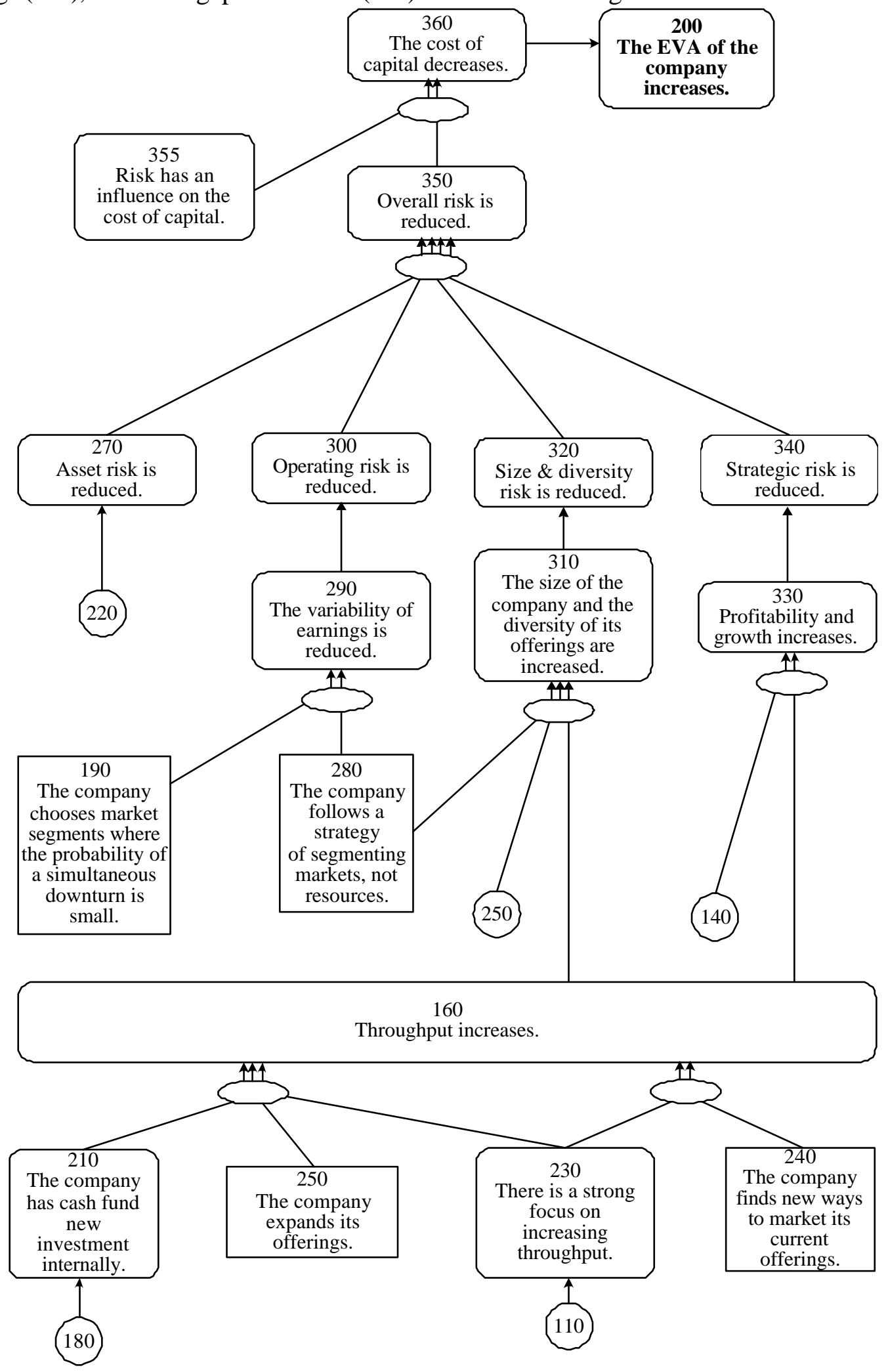

Figure 2. Applying TOC measurements future reality tree (continued) 
throughput (230) and the company has cash to fund new investment internally (210) and the company expands its offerings (250), then throughput increases (160).

Stewart [2] identifies four factors which are statistically significant in terms of the risk premiums attached to the cost of capital of a business: operating risk, strategic risk, asset risk and size \& diversity risk. Operating risk takes into account variations in pretax returns, after tax returns, total gross returns, operating cash flow and capital growth rate. Strategic risk is associated with the profitability and growth rates of the business. Asset risk consists of working capital management and fixed asset management, which are measured for example by the amount of working capital needed, inventory days on hand, average life of assets, newness of plant and expected plant life. Size \& diversity risk is associated with smaller companies having to take more risk per individual decision, and with geographic and product diversity [2].

If the asset management of the company improves (220), then asset risk is reduced (270). If the company chooses market segments where the probability of a simultaneous downturn is small (190), and the company follows a strategy of segmenting markets, not resources (280), then the variability of earnings is reduced (290). If the variability of earnings is reduced (290) then operating risk is reduced (300). If the company follows a strategy of segmenting markets, not resources (280), and the company expands its offerings (250) and throughput increases (160), then the size of the company and the diversity of its offerings are increased (310). If the size of the company and the diversity of its offerings are increased (310) then size \& diversity risk is reduced (320). If operating expenses decrease (140) and throughput increases (160) then profitability and growth increases (330). If profitability and growth increases (330) then strategic risk is reduced (340). If asset risk is reduced (270) and operating risk is reduced (300) and size \& diversity risk is reduced (320) and strategic risk is reduced (340), then overall risk is reduced (350). Since risk influences the cost of capital (355), and overall risk is reduced (355), the cost of capital decreases (360). If the cost of capital decreases (360), then the EVA of the company increases (200) (see equation (6)).

It is important to note that the future reality tree contains a reinforcing (or positive feedback) loop: through entity 180 to 210 to 160 . Therefore, if the company has increasing cash flow (180), it can use this to fund investment internally as long as there is new offerings to the market (210 and 250), and throughput will continue to increase (160). In this case, the company might not need to raise external cash to fund future growth.

\section{Creating the future}

The future reality is the logical consequence of the injections and the entities currently existing in the organisation. The management of the company must implement the injections, and the effects will happen. The following injections need to be implemented:

- the company decides to manage according to TOC principles, and implements the decision (90);

- the company finds new ways to market its current offerings (240);

- the company expands its offerings (250);

- the company chooses market segments where the probability of a simultaneous downturn is small (190); and

- the company follows a strategy of segmenting markets, not resources (280). 
Injection 90 is the act of convincing management to decide to manage according to TOC principles, injections 190, 240, 250 and 280 are the formulation of a new company strategy. How to implement these injections in a company, is explained in the second part of the paper [23].

\section{Conclusions}

If a company is managed according to TOC principles, the EVA of the company will improve. This is due to the fact that net profit, return on investment and cash flow will increase due to the focus on the constraints of the company. At the same time, the asset risk, operating risk, size \& diversity risk and the strategic risk of the company will be reduced. Therefore the risk factors that influence the cost of capital of the company will be reduced, leading to a reduction in the cost of capital. Both terms (return on investment and cost of capital) that form part of the EVA equation are therefore influenced in favourable directions by applying TOC management principles.

\section{References}

[1] Eliyahu M. Goldratt and Jeff Cox. The goal: a process of ongoing improvement. Avraham Y. Goldratt Institute, Pretoria, 2nd revised edition, 1992.

[2] G. Bennett Stewart. The quest for value: the EVA(TM) management guide. HarperCollins, 1990.

[3] Ben Temkin. Add value or fail. Financial Mail, 7 July 2000. Internet: http://www.fm.co.za/ 00/0707/covopin/cover.htm Access: 28 September 2000.

[4] James Eedes. Loving EVA. Financial Mail, 19 November 1999. Internet: http://www.fm.co. za/99/1119/personal/apers.htm Access: 28 September 2000.

[5] Shawn Tully. A better taskmaster than the market? Fortune, 138 no 8:277+, 26 October 1998.

[6] Randall Tobias and Justin Martin. Eli Lilly is making shareholders rich. How? By linking pay to EVA. Fortune, 134 no 5:173+, 9 September 1996.

[7] Russell L. Ackoff. Ackoff's best: his classic writings on management. John Wiley \& Sons, New York, 1999.

[8] Jamshid Gharajedaghi. Systems thinking: managing chaos and complexity: a platform for de-signing business architecture. Butterworth-Heinemann, Boston, 1999.

[9] Eliyahu M. Goldratt. The haystack syndrome: sifting information out of the data ocean. North River Press, Great Barrington, 1990.

[10]Eliyahu M. Goldratt. It's not luck. Avraham Y. Goldratt Institute, Pretoria, 1994.

[11] Alfred Rappaport. Creating shareholder value: a guide for managers and investors. The Free Press, New York, 2nd edition, 1998.

[12]Eliyahu M. Goldratt. Essays on the theory of constraints. North River Press, Great Barrington, 1987-1990.

[13]Eliyahu M. Goldratt. Goldratt satellite programme viewer notebook. 1999.

[14]Gerald I. Kendall. Securing the future: strategies for exponential growth using the theory of constraints. St. Lucie Press/APICS series on constraints management. St. Lucie Press, Boca Raton, 1998.

[15] Ciaran Walsh. Key management ratios: how to analyze, compare and control the figures that drive company value. Financial Times/Prentice Hall, Harlow, 1996. 
[16] Malan Smith and Pieter Pretorius. Exposing the false paradigm used in management decision making. South African Journal of Industrial Engineering, Vol 12 No 2, May 2001.

[17] Thomas Corbett. Throughput accounting: TOC's management accounting system. North River Press, Great Barrington, 1998.

[18] Malan Smith. Applying the theory of constraints to increase economic value added. Masters project report, University of Pretoria, October 2000.

[19]H. William Dettmer. Breaking the constraints to world-class performance. American Society for Quality, Milwaukee, 1998.

[20]H. William Dettmer. Goldratt's theory of constraints: a systems approach to continuous improvement. American Society for Quality, Milwaukee, 1997.

[21] Thomas B. McMullen. Introduction to the theory of constraints (TOC) management system. St. Lucie Press/APICS series on constraints management. St. Lucie Press, Boca Raton, 1998.

[22] Richard Koch. The Financial Times guide to strategy. Pitman, London, 2nd edition, 1995.

[23] Malan Smith and Pieter Pretorius. Applying the theory of constraints to increase economic value added: Part 2-Implementation. Unpublished manuscript. 2001.

[24]Eliyahu M. Goldratt and Robert E. Fox. The Race. North River Press, New York. 1986. 